\title{
PENGARUH PENERAPAN AKUNTANSI PERTANGGUNGJAWABAN TERHADAP KINERJA MANAJERIAL DENGAN MOTIVASI SEBAGAI VARIABEL INTERVENING (SURVEI PADA PT TAMAN WISATA CANDI BOROBUDUR, PRAMBANAN,DAN RATU BOKO)
}

\author{
THE EFFECTOF THE ACCOUNTING RESPONSIBILITY \\ IMPLEMENTATION TOWARDS MANAGERIAL PERFORMANCE WITH \\ MOTIVATION AS INTERVENING VARIABLE (SURVEY INPT TAMAN \\ WISATA CANDI BOROBUDUR, PRAMBANAN, AND RATU BOKO)
}

\author{
Linda Dyah Kinasih \\ Prodi Akuntansi Universitas negeri Yogyakarta \\ lindadyah@gmail.com \\ Mimin Nur Aisyah, M.Sc., Ak. \\ Staf Pengajar Jurusan P. Akuntansi Universitas Negeri Yogyakarta
}

Fakultas Ekonomi Universitas Negeri Yogyakarta

\begin{abstract}
ABSTRAK
Penelitian ini bertujuan untuk mengetahui pengaruh penerapan akuntansi pertanggungjawaban terhadap kinerja manajerial melalui motivasi. Penelitian ini adalah penelitian kausal komparatif di mana data yang digunakan diperoleh melalui survei dengan penyebaran kuesioner.Sampel dalam penelitian ini mencakup manajer pusat pertanggungjawaban diPT Taman Wisata Candi Borobudur, Prambanan dan Ratu Boko.Teknik analisis data menggunakan metode path analysisyang dibantu komputer menggunakan software SPSS 17.0 for Windows. Hasil penelitian menemukan adanyapengaruh positif dan signifikan penerapan akuntansi pertanggungjawaban terhadap kinerja manajerial yang ditunjukkan melalui nilai koefisien korelasi (R) sebesar 0,552 dan nilai $t$ hitung $>\mathrm{t}$ tabel pada taraf signifikansi $5 \%(6.810>1,6594)$. Kemudian pengaruh positif dan signifikan penerapan akuntansi pertanggungjawaban terhadap motivasi ditunjukkan melalui nilai koefisien korelasi $(\mathrm{R})$ sebesar 0,713 dan nilai $\mathrm{t}$ hitung $>\mathrm{t}$ tabel $(10,481>1,6594)$. Terakhir, terdapat pengaruh positif dan signifikan penerapan akuntansi pertanggungjawaban terhadap kinerja manajerial melalui motivasi yang ditunjukkan dari hasil penjumlahan koefisien sebesar 0,379 yang kemudian diuji menggunakan Sobel Test dan menghasilkan $t$ hitung $>\mathrm{t}$ tabel pada taraf signifikansi $5 \%(2,699>1,6594)$.
\end{abstract}

Kata kunci : Akuntansi Pertanggungjawaban, Kinerja Manajerial, Motivasi

\section{ABSTRACT}

This researchis aimed at determining the effect of responsibility accounting implementation on managerial performance through motivation. This researchused the data obtained through questionnaire distribution. The sample was the responsibility center managersin PT Taman Wisata Candi Borobudur, Prambanan and Ratu Boko. Path analysis method was used to analyze the data with the help ofSPSS 17.0 for Windows. The result finda positive and significant effect ofthe implementation of 


\section{JURNAL NOMINAL / VOLUME II NOMOR II / TAHUN 2013}

responsibility accounting to the managerial performance shown by the coefficient of correlation $(R)$ of 0.552 and the value of $t$ count $>t$ table(6.810>1.6594)at significance level of 5\%. Then, a positive and significant effect of responsibility accounting implementation on motivation is shown by the coefficient of correlation $(R)$ of 0.713 and the value of $t$ count $>t$ table $(10.481>1.6594)$. Lastly, a positive and significant effect ofthe implementation of responsibility accounting on managerial performance through motivation is shown by the total coefficient of 0.379 which then tested usingSobel test and produce t count $>$ t table at the 5\% significance level (2.699> 1.6594$)$.

Keywords: Responsbility Accounting, Managerial Performance, Motivation

\section{A. PENDAhuluan}

Setiap perusahaan memiliki visi-misi yang ingin dicapai sebagai dasar dalam menjalankan perusahaan. Dalam perjalanan mencapai visi-misi tersebut, pengaruh lingkungan di mana perusahaan berkembang akan sangat berpengaruh. Pengaruh lingkungan tersebut bisa saja menghambat perusahaan untuk berkembang.

Agar perusahaan dapat menyesuaikan diri dengan perubahan yang ada,maka tugas manajemen menjadi semakin berat.Untuk mengatasi permasalahan tersebut, desentralisasi banyak dipilih oleh perusahaan agar dapat meningkatkan efisiensi secara keseluruhan.Penerapan desentralisasi tersebut menyebabkan pentingnya penilaian kinerja dalam perusahaan secara individual.

Untuk mengetahui baik tidaknya kinerja manajerial maka perusahaan melakukan penilaian kinerja untuk setiap individu manajer. Adapun unsur-unsur dari kinerja yang akan dinilai dalam penilaian kinerja menurut Robert dan John (2006:378) meliputi kuantitas dari hasil, kualitas dari hasil, ketepatan waktu dari hasil, kehadiran dan kemampuan bekerja sama. Semua unsur tersebut akan menjadi dasar untuk mengukur kinerja setiap individu. Menurut Mahoney et.al (1963) kinerja dari individu tersebut dapat diukur dengan menggunakan indikator kegiatan-kegiatan manajerial seperti perencanaan, investigasi, pengkoordinasian, evaluasi, pengawasan, staffing (pengaturan staf), negosiasi dan perwakilan/represtatif.

Akuntansi pertanggungjawaban perlu diterapkan untuk mempermudah penilaian kinerja manajerial.Akuntansi pertanggungjawaban merupakan istilah yang digunakan untuk menjelaskan akuntansi perencanaan dalam penyusunan anggaran serta mengukur dan mengevaluasi kinerja perusahaan sepanjang garis pertanggungjawaban (Mulyadi, 1997). 


\section{JURNAL NOMINAL / VOLUME II NOMOR II / TAHUN 2013}

Akuntansi pertanggungjawaban diduga memiliki pengaruh langsung maupun tidak langsung terhadap kinerja manajerial. Pengaruh langsung tersebut adalah penerapan akuntansi pertanggungjawaban yang baik akan membantu manajemen perusahaan untuk menilai kinerja dari setiap pusat pertanggungjawaban dalam rangka pengambilan keputusan dan mencapai visi-misi perusahaan secara menyeluruh dan maksimal.

Selanjutnya, pengaruh tidak langsung tersebut adalah penerapan akuntansi pertanggungjawaban yang baik dapat membantu mempermudah pekerjaan manajer yang sulit dalam mengambil keputusan yang harus diambilnya, sehingga pekerjaannya dapat diselesaikan dengan baik.Pekerjaan sulit yang dapat diselesaikan dengan baik dapat membuat manajer merasa puas dalam bekerja, sehingga timbul motivasi dari manajer tersebut untuk terus berusaha bekerja dengan baik. Ketika motivasi untuk bekerja tinggi maka kinerja pun akan menjadi baik. Hal ini seperti yang diungkapkan Wardhani dalam Oktaviani (2012) yaitu sistem akuntansi pertanggungjawaban yang diterapkan secara baik pada setiap bagian dapat memberikan kemudahan bagi pimpinan dalam pengambilan keputusan manajemen, sehingga dapat menimbulkan kepuasan kerja manajer karena berhasil menyelesaikan suatu pekerjaan.

Menurut Listianto dan Setiaji (2007) apabila pekerjaan yang dibebankan kepada manajer dapat selesai dengan tepat dan cepat, maka dapat diartikan bahwa manajer tersebut memiliki semangat kerja yang tinggi.Pekerjaan yang dengan tepat dan cepat selesai merupakan suatu prestasi kerja yang baik. Prestasi kerja yang baik akan memberikan dampak yang baik pula bagi perusahaan. Oleh sebab itu manajemen perusahaan harus memiliki sistem yang dapat membantu pekerjaan manajer agar dapat tepat dan cepat selesai, sehingga dapat menumbuhkan motivasi bekerja pada manajer untuk berprestasi.Motivasi untuk berprestasi tersebut dapat berefek pada pencapaian tujuan organisasi.

PT Taman Wisata Candi Borobudur, Prambanan dan Ratu Boko adalah Badan Usaha Milik Negara yang khusus bergerak dalam usaha pengelolaan objek wisata Candi Borobudur, Candi Prambanan dan Ratu Boko. PT Taman Wisata Candi Borobudur, Prambanan dan Ratu Boko melakukan pengelolaan, pemanfaatan dan pemeliharaan ketertiban serta kebersihan kawasan beserta candi yang digunakan 


\section{JURNAL NOMINAL / VOLUME II NOMOR II / TAHUN 2013}

sebagai objek dan daya tarik wisata berdasarkan petunjuk teknis Direktorat Jenderal Sejarah dan Purbakala, Kementrian Kebudayaan dan Pariwisata (-, 2013). Taman wisata ini sudah didirikan sejak tahun 1980 dan dapat bertahan hingga sekarang. Selama beberapa tahun dalam proses bertahan untuk menjaga eksistensinya pasti sudah banyak sekali perubahan yang terjadi pada taman wisata ini. Perubahan tersebut pasti dipengaruhi oleh lingkungan luar perusahaan.Untuk menyesuaikan dari pengaruh lingkungan luar perusahaan tersebut, maka peranan manajer sangat dominan.Peran manajer tersebut adalah dalam mengambil keputusan strategik pada setiap keputusan bisnis yang harus diambilnya.Untuk memudahkan pengambilan keputusan bisnis tersebut, manajer dapat dibantu oleh informasi akuntansi yang dihasilkan dari penerapan akuntansi pertanggungjawaban pada perusahaan.

Berdasarkan wawancara yang telah dilakukan, dapat disimpulkan bahwa akuntansi pertanggungjawaban yang sudah diterapkan oleh PT Taman Wisata Candi Borobudur, Prambanan dan Ratu Boko sudah cukup baik dan memadai dilihat dari syarat akuntansi pertanggungjawaban yang telah dipenuhi oleh perusahaan. Syarat tersebut adalah adanya struktur organisasi yang jelas, partisipasi penyusunan anggaran oleh setiap tingkatan manajemen, adanya penggolongan biaya yang dapat dikendalikan dan tidak dapat dikendalikan, adanya pengklasifikasian kode-kode rekening sesuai tingkatan manajemen, dan laporan pertanggungjawaban mengenai rekapitulasi biaya yang harus dibuat oleh tiap-tiap pusat biaya. Akan tetapi partisipasi penyusunan anggaran yang menjadi syarat diterapkannya akuntansi pertanggungjawaban kurang begitu terasa pada individu manajer. Penyusunan anggaran hanya diambil dari realisasi tahun sebelumnya yang kemudian dinegoisasikan dengan kantor pusat. Hal tersebut bisa saja mengakibatkan penerapan akuntansi pertanggungjawaban kurang maksimal, motivasi bekerja karyawan tidak tinggi, sehingga kinerja masing-masing manajer menjadi kurang efektif.

Motivasi untuk bekerja juga cukup tinggi dilihat dari rendahnya tingkat absensi kerja.Lingkungan kerja di perusahaan yang sangat nyaman menjadi salah satu faktor yang membuat motivasi bekerja cukup tinggi.Akan tetapi lingkungan kerja yang terlalu nyaman justru bisa menjadikan rendahnyatantangan yang 
dirasakan dalam bekerja sehingga motivasi bekerja pun berkurang dan pada akhirnya membuat kinerja kurang maksimal.

Motivasi bekerja yang cukup tinggi sedikit banyak akan berpengaruh pada kinerja karyawan dalam perusahaan. Kinerja karyawan pada PT Taman Wisata Candi Borobudur, Prambanan dan Ratu Boko cukup baik.Hal ini dapat dilihat dari kenaikan laba yang diperoleh PT Taman Wisata Candi Borobudur, Prambanan dan Ratu Boko pada tahun 2010-2012. Pada tahun 2010 laba yang dicapai perusahaan sebesar Rp 12 Milyar, tahun 2011 laba yang diperoleh sebesar Rp 13 Milyar atau mengalami kenaikan sebesar Rp 1 Milyar. Pada tahun 2012 laba yang dicapai sebesar Rp 29 Milyar atau mengalami kenaikan sebesar Rp 16 Milyar dari tahun 2011.

Berdasarkan latar belakang tersebut, penulis tertarik untuk melakukan penelitian dengan judul "Pengaruh Penerapan Akuntansi Pertanggungjawaban terhadap Kinerja Manajerial dengan Motivasi sebagai Variabel Intervening (Survei pada PT Taman Wisata Candi Borobudur, Prambanan dan Ratu Boko)".

\section{B. METODE PENELITIAN}

\section{Jenis Penelitian}

Penelitian ini adalah penelitian kausal komparatif yang mencoba untuk menentukan alasan atau penyebab untuk kondisi yang ada.

\section{Waktu dan Tempat Penelitian}

Penelitian ini akan dilaksanakan pada PT Taman Wisata Candi Borobudur, Prambanan dan Ratu Boko yang beralamat di Jalan Raya Jogya-Solo Km 16 Prambanan, Sleman, Yogyakarta 55571. Penelitian ini dilaksanakan pada bulan April - Mei tahun 2013.

\section{Target/Subjek Penelitian}

Pada penelitian ini, populasi yang diambil adalah manajer pada PT Taman Wisata Candi Borobudur, Prambanan dan Ratu Boko.Pemilihan sampel dalam penelitian ini dilakukan dengan metode purposive sampling yaitu manajer pusat pertanggungjawaban pada PT Taman Wisata Candi Borobudur, Prambanan dan Ratu Bokosehingga apabila dijumlahkan 
keseluruhan sampel yang digunakan dalam penelitian ini berjumlah 108 responden.

\section{Prosedur}

Data yang digunakan dalam penelitian ini diperoleh melalui survei.Penulis memberikan kuesioner pada PT Taman Wisata Candi Borobudur, Prambanan dan Ratu Boko. Kuesioner yang menjadi instrumen dalam teknik pengumpulan data diberikan beserta dengan surat permohonan dan penjelasan mengenai tujuan penelitian yang dilakukan. Kuesioner ini dititipkan pada sekretariat PT Taman Wisata Candi Borobudur, Prambanan dan Ratu Boko.

\section{Data, Instrumen, dan Teknik Pengumpulan}

\section{a). Data}

Data merupakan instrumen yang penting dalam penelitian.Jenis data yang digunakan dalam penelitian ini adalah data primer.Untuk variabel independen yaitu penerapan akuntansi pertanggungjawaban, menggunakan teori yang dikembangkan Hansen-Mowen dan Mulyadi yang diadopsi dari instrumen yang digunakan Diana Putri (2005) dan Al-Bawab (2012).Untuk variabel dependen yaitu kinerja manajerial diukur dengan menggunakan instrumen self rating yang dikembangkan oleh Mahoney, dkk.(1963) yang diadopsi oleh Laberto (2001).Untuk variabel intervening yaitu motivasi, diukur dengan menggunakan teori Maslow dengan mengadopsi instrumen yang digunakan oleh Risanti (2012).

\section{b). Teknik Analisis Data}

Berikut ini beberapa uji yang dilakukan dalam penelitian ini, yaitu:

\section{1) Uji Instrumen}

\section{(a) Uji Validitas}

Uji validitas digunakan untuk mengukur sah atau valid tidaknya suatu kuesioner.Uji signifikansi dilakukan dengan membandingkan nilai $\mathrm{r}$ hitung dengan $\mathrm{r}$ tabel untuk degree of freedom $(\mathrm{df})=\mathrm{n}-2$. Jika $\mathrm{r}$ hitung lebih besar dari $\mathrm{r}$ tabel dan nilai $\mathrm{r}$ positif maka pertanyaan tersebut dikatakan valid (Imam Ghozali, 
2011).Uji validitas yang digunakan dalam penelitian ini adalah dengan menggunakan metode korelasi product moment pearsondari Karl Pearson.

(b) Uji Reliabilitas

Reliabilitas adalah alat untuk mengukur suatu kuesioner yang merupakan indikator dari variabel atau konstruk.Untuk menguji reliabilitas ini digunakan uji statistik Cronbach Alpha $(\alpha)$.Suatu konstruk atau variabel dikatakan reliable jika memberikan nilai Cronbch Alpha > 0.70 (Nunnaly, 1994 dalam Imam Ghozali, 2011).

\section{2) Uji Asumsi Klasik}

\section{(a) Uji Normalitas}

Uji normalitas bertujuan untuk menguji apakah dalam model regresi variabel residual atau pengganggu memiliki distribusi normal.Pengujian normalitas dalam penelitian ini menggunakan uji statistik Kolmogorov-Smirnov.

\section{(b) Uji Linearitas}

Uji linearitas bertujuan untuk mengetahui apakah variabel independen dan variabel dependen mempunyai hubungan linear atau tidak.Perhitungan statistik dalam pengujian ini menggunakan Uji Lagrange Multiplier.Nilai $c^{2}$ hitung didapatkan dari perkalian $\mathrm{R}^{2}$ dan $\mathrm{n}$ (jumlah responden). Apabila $\mathrm{c}^{2}$ hitung $<\mathrm{c}^{2}$ tabel (pada taraf signifikansi 5\%), maka dapat disimpulkan bahwa model linear diterima.

\section{(c) Uji Multikolinearitas}

Uji multikolinearitas bertujuan untuk menguji apakah model regresi ditemukan adanya korelasi antar variabel bebas (independen). Untuk mendeteksi ada tidaknya multikolinearitas di dalam model regresi maka akan digunakan penilaian Variance Inflation Factor (VIF) atauTolerance Value. Model regresi dikatakan mengalami multikolinearitas apabila nilai tolerance $\leq$ 0,10 dengan nilai $\mathrm{VIF} \geq 10$. 


\section{(d) Uji Heteroskedastisitas}

Uji heteroskedastisitas bertujuan menguji apakah dalam model regresi terjadi ketidaksamaan variance dari residual satu pengamatan ke pengamatan lainnya.Dalam penelitian ini untuk mendeteksi ada atau tidaknya heteroskedastisitas digunakan uji Glejser.

\section{3) Uji Hipotesis}

(a) Uji Hipotesis 1 dan Hipotesis 2

Hipotesis 1 dan Hipotesis 2 diuji dengan menggunakan analisis regresi linear sederhana.Pengambilan kesimpulan dilakukan dengan $\mathrm{t}$ hitung dengan $\mathrm{t}$ tabel dengan taraf signifikansi 5\%.Apabila nilai t hitung lebih tinggi dibandingkan nilai t tabel, maka variabel memiliki pengaruh yang signifikan.

(b) Uji Hipotesis 3

Hipotesis 3 diuji dengan menggunakan path analysis.

\section{HASIL PENELITIAN DAN PEMBAHASAN}

\section{Hasil Penelitian}

a. Statistik Deskripsif

Tabel 1. Statistik Deskriptif

\begin{tabular}{|l||c|c||c|c||}
\hline \multicolumn{1}{|c|}{ Variabel } & $\begin{array}{l}\text { Kisaran } \\
\text { Teoritis }\end{array}$ & $\begin{array}{c}\text { Kisaran } \\
\text { Sesungguhnya }\end{array}$ & Rata-rata & $\begin{array}{c}\text { Standar } \\
\text { Deviasi }\end{array}$ \\
\hline $\begin{array}{l}\text { Penerapan Akuntansi } \\
\text { Pertanggungjawaban } \\
\text { (Xa) }\end{array}$ & $23-92$ & $60-92$ & 78,58 & 6,042 \\
\hline Motivasi (Xb) & $15-60$ & $44-59$ & 51,25 & 3,491 \\
\hline Kinerja Manajerial (Y) & $9-54$ & $33-51$ & 41,79 & 4,154 \\
\hline
\end{tabular}

\section{b. Uji Instrumen}

\section{1) Uji Validitas}

Pada penelitian ini nilai $\mathrm{r}$ tabel $(\mathrm{N}-2)$ untuk responden sebanyak 108 orang adalah 0,1591 (Imam Ghozali, 2011: 438). Metode pearson correlation menyatakan butir pertanyaan dikatakan valid apabila signifikansi butir pertanyaan $(1$-tailed $) \leq 0,05$ dan atau $\geq 0,01$. 
Tabel 2. Hasil Uji Validitas

\begin{tabular}{|c|c|c|}
\hline $\begin{array}{c}\text { Jumlah } \\
\text { Pertanyaan }\end{array}$ & Jumlah Valid & Gugur \\
\hline 23 & 23 & 0 \\
\hline 15 & 15 & 0 \\
\hline 9 & 9 & 0 \\
\hline
\end{tabular}

\section{2) Uji Reliabilitas}

Suatu variabel atau konstruk dikatakan reliabel apabila nilai Cronbach Alpha masing-masing variabel > 0,70 (Nunnaly, 1994 dalam Imam Ghozali, 2011). Dalam tabel berikut ini disajikan hasil uji reliabilitas.

Tabel 3. Hasil Uji Reliabilitas

\begin{tabular}{|l|c|}
\hline \multicolumn{1}{|c|}{ Variabel } & Cronbach's Alpha \\
\hline Penerapan Akuntansi Pertanggungjawaban & 0,876 \\
\hline Motivasi & 0,744 \\
\hline Kinerja Manajerial & 0,852 \\
\hline
\end{tabular}

Tabel diatas menunjukkan nilai cronbach'salpha instrumen variabel penerapan akuntansi pertanggungjawaban sebesar 0,876, instrumen variabel motivasi sebesar 0,744 dan instrumen variabel kinerjamanajerial sebesar 0,852. Hal tersebut berarti instrumen variabel penerapan akuntansi pertanggungjawaban, motivasi dan instrumen variabel kinerja manajerial adalah handal atau reliabel untuk digunakan dalam pengolahan data.

\section{c. Uji Asumsi Klasik}

1) Uji Normalitas

Tabel 4. Hasil Uji Normalitas

\begin{tabular}{|c|c|c|}
\hline & & $\begin{array}{l}\text { Unstandard } \\
\text { ized Residual }\end{array}$ \\
\hline \multicolumn{2}{|l|}{$\mathrm{N}$} & 108 \\
\hline \multirow{2}{*}{$\begin{array}{c}\text { Normal } \\
\text { Parameters }\end{array}$} & Mean & .0000000 \\
\hline & Std. Deviation & 3.34194981 \\
\hline \multirow{3}{*}{$\begin{array}{l}\text { Most Extreme } \\
\text { Differences }\end{array}$} & Absolute & .100 \\
\hline & Positive & .100 \\
\hline & Negative & -.070 \\
\hline \multicolumn{2}{|c|}{ Kolmogorov-Smirnov Z } & 1.035 \\
\hline \multicolumn{2}{|c|}{ Asymp. Sig. (2-tailed) } & .234 \\
\hline
\end{tabular}

Berdasarkan hasil uji normalitas di atas, karena nilai Asymp. Sig. di atas 0,05 maka dapat disimpulkan bahwa data berdistribusi normal. 


\section{2) Uji Linearitas}

Tabel 5. Hasil Uji Linearitas

\begin{tabular}{c|c|c|c|c|}
\hline $\mathbf{R 2}$ & $\mathbf{N}$ & $\begin{array}{c}\text { C2 } \\
\text { hitung }\end{array}$ & $\begin{array}{c}\text { C2 } \\
\text { tabel }\end{array}$ & Keterangan \\
\hline 0,000 & 108 & 0 & 124,342 & Linear \\
\hline
\end{tabular}

Berdasarkan hasil uji linearitas pada tabel 16. menunjukkan bahwa c2 hitung (0) lebih kecil dari c2 tabel(124,342) yang menunjukkan bahwa hubungan tersebut adalah linear.

\section{3) Uji Multikolinieritas}

Tabel 6. Hasil Uji Multikolinieritas

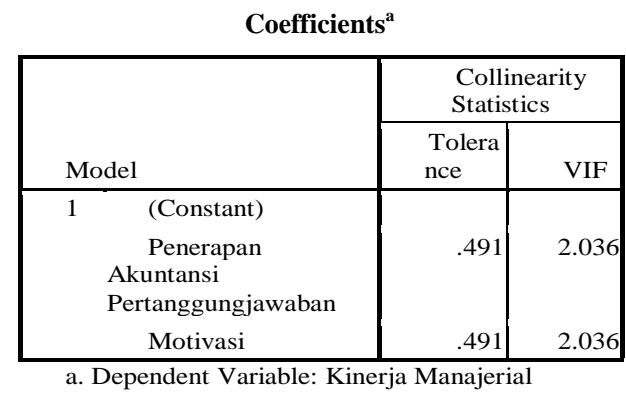

Karena nilai Tolerance di atas 0,1 dan VIF $<10$ maka dapat disimpulkan bahwa tidak ada multikolonieritas dalam model regresi.

\section{4) Uji Heteroskedastisitas}

Tabel 7. Hasil Uji Heteroskedastisitas

\section{Coefficients $^{\mathrm{a}}$}

\begin{tabular}{|c|c|c|c|c|c|c|}
\hline \multirow[b]{2}{*}{ Model } & & \multicolumn{2}{|c|}{$\begin{array}{l}\text { Unstandardized } \\
\text { Coefficients }\end{array}$} & \multirow{2}{*}{\begin{tabular}{|c}
$\begin{array}{r}\text { Standardiz } \\
\text { ed Coefficients }\end{array}$ \\
Beta \\
\end{tabular}} & \multirow[b]{2}{*}{$\mathrm{T}$} & \multirow[b]{2}{*}{ Sig. } \\
\hline & & $\mathrm{B}$ & $\begin{array}{c}\text { Std. } \\
\text { Error }\end{array}$ & & & \\
\hline & (stant) & $\begin{array}{r}1.32 \\
1\end{array}$ & 2.62 .5 & & .503 & .616 \\
\hline $\begin{array}{l}\mathrm{Per} \\
\mathrm{Ak} \\
\mathrm{Per}\end{array}$ & $\begin{array}{l}\text { rapan } \\
\text { ntansi } \\
\text { anggungjawaban }\end{array}$ & .042 & .041 & .142 & 1.029 & .306 \\
\hline Mo & ivasi & .035 & .071 & -.069 & -.501 & .618 \\
\hline
\end{tabular}

Dari hasil uji Glejser di atas menunjukkan bahwa tidak ada satupun variabel independen yang signifikan secara statistik mempengaruhi variabel dependen nilai absolut Ut (Abs_ut).Hal ini terlihat dari probabilitas signifikansinya di atas 
5\%.Jadi dapat disimpulkan bahwa model regresi tidak mengandung adanya heteroskedastisitas.

\section{d. Uji Hipotesis}

\section{1) Hipotesis 1}

Tabel 8. Ringkasan Hasil Uji Hipotesis 1

\begin{tabular}{|l|c|c||c|c|c|c|}
\hline \multirow{2}{*}{ Variabel } & \multicolumn{2}{|c|}{$\begin{array}{c}\text { Unstandardized } \\
\text { Coefficients }\end{array}$} & \multirow{2}{*|}{ S } & Sig. & $\mathrm{R}$ & $\mathrm{R}^{2}$ \\
\cline { 2 - 7 } & $\mathrm{B}$ & $\begin{array}{c}\text { Standard } \\
\text { Error }\end{array}$ & $\mathrm{t}$ & & & \\
\hline $\begin{array}{l}\text { Kinerja } \\
\text { Manajerial (Y) }\end{array}$ & 11.985 & 4.389 & 2.730 & 0.007 & 0.552 & 0.304 \\
$\begin{array}{l}\text { Penerapan } \\
\text { Akuntansi } \\
\text { Pertanggungjawa } \\
\text { ban (Xa) }\end{array}$ & 0.379 & 0.056 & 6.810 & 0.000 & & \\
\hline
\end{tabular}

Dari tabel dapat diperoleh persamaan regresi sebagai berikut:

$$
\mathrm{Y}=11.985+0.379 \mathrm{Xa}
$$

Konstanta sebesar 11,985 menunjukkan bahwa jika variabel independen dianggap nol, maka nilai Kinerja Manajerial adalah 11,985. Koefisien regresi Penerapan Akuntansi Pertanggungjawaban (Xa) sebesar 0,379 menyatakan bahwa setiap kenaikan Penerapan Akuntansi Pertanggungjawaban sebesar 1 satuan akan menaikkan Kinerja Manajerial sebesar 0,379 satuan. Hal ini berarti arah model tersebut adalah positif.Arah positif tersebut juga dapat dilihat dari nilai korelasi regresi (R) yang bernilai positif antara Penerapan Akuntansi Pertanggungjawaban dan Kinerja Manajerial sebesar 0,552.Dari tabel juga dapat dilihat bahwa $\mathrm{R}$ Square sebesar 0,304.Hal ini berarti peranan variabel independen dalam mengukur variabel dependen sebesar 30,4\% sedangkan 69,6\% dipengaruhi oleh faktor-faktor lainnya yang tidak diteliti dalam model regresi

Nilai $\mathrm{t}$ hitung sebesar 6,810 (di atas nilai $\mathrm{t}$ tabel yaitu 1,6594) mengindikasikan bahwa variabel Penerapan Akuntansi Pertanggungjawaban berpengaruh secara signifikan terhadap variabel Kinerja Manajerial. Hal ini juga didukung dengan nilai signifikansi sebesar 0,000 lebih kecil dari level of signifikansi (sig < 5\%) berarti terdapat pengaruh signifikan antara variabel independen terhadap variabel dependen secara individual.Hasil uji regresi ini mendukung hipotesis 1 yang menyatakan bahwa penerapan akuntansi pertanggungjawaban mempunyai pengaruh positif terhadap kinerja manajerial. 
2) Hipotesis 2

Tabel 9. Ringkasan Hasil Uji Hipotesis 2

\begin{tabular}{|l|c|c|c|c|c|c|}
\hline \multirow{2}{*}{ Variabel } & \multicolumn{2}{|c|}{$\begin{array}{c}\text { Unstandardized } \\
\text { Coefficients }\end{array}$} & \multirow{2}{*}{$\mathrm{T}$} & Sig. & $\mathrm{R}$ & $\mathrm{R}^{2}$ \\
\cline { 2 - 4 } & $\mathrm{B}$ & $\begin{array}{c}\text { Standard } \\
\text { Error }\end{array}$ & $\mathrm{T}$ & & & \\
\hline Motivasi (Y) & 18.856 & 3.100 & 6.803 & 0.000 & 0.713 & 0.509 \\
$\begin{array}{l}\text { Penerapan } \\
\text { Akuntansi } \\
\text { Pertanggungjawa } \\
\text { ban (Xa) }\end{array}$ & 0.412 & 0.039 & 10.481 & 0.000 & &
\end{tabular}

Dari tabel dapat diperoleh persamaan regresi sebagai berikut:

$\mathrm{Y}=18.856+0.412 \mathrm{Xa}$

Konstanta sebesar 18,856menunjukkan bahwa jika variabel independen dianggap nol, maka nilaiMotivasi adalah sebesar 18,856. Koefisien regresi Penerapan Akuntansi Pertanggungjawaban (Xa) sebesar 0,412 menyatakan bahwa setiap kenaikan Penerapan Akuntansi Pertanggungjawaban sebesar 1 satuan akan menaikkan Motivasi sebesar 0,412 satuan. Hal ini berarti arah model tersebut adalah positif.Arah positif tersebut juga dapat dilihat dari nilai korelasi regresi (R) yang bernilai positif antara Penerapan Akuntansi Pertanggungjawaban dan Motivasi sebesar 0,713.Dari tabel dapat dilihat bahwa R Square sebesar 0,509. Hal tersebut berarti peranan variabel independen dalam mengukur variabel dependen sebesar 50,9\% sedangkan 49,1\% dipengaruhi oleh faktor-faktor lainnya yang tidak diteliti dalam model regresi.

Nilai $\mathrm{t}$ hitung sebesar 10,481 (di atas nilai $\mathrm{t}$ tabel yaitu 1,6594) mengindikasikan bahwa variabel Penerapan Akuntansi Pertanggungjawaban berpengaruh secara signifikan terhadap variabel Motivasi. Hal ini juga didukung dengan nilai signifikansi sebesar 0,000 lebih kecil dari level of signifikansi (sig < $5 \%$ ) berarti terdapat pengaruh signifikan antara variabel independen terhadap variabel dependen secara individual.Hasil uji regresi ini mendukung hipotesis 2 yang menyatakan bahwa penerapan akuntansi pertanggungjawaban mempunyai pengaruh positif terhadap motivasi. 
3) Hipotesis 3

Tabel 10. Ringkasan Hasil Uji Hipotesis 3

\begin{tabular}{||l||c|c|c|c||c|c|}
\hline \multirow{2}{*}{ Variabel } & \multicolumn{2}{|c|}{$\begin{array}{c}\text { Unstandardized } \\
\text { Coefficients }\end{array}$} & \multirow{2}{*}{$\mathrm{t}$} & Sig. & $\mathrm{R}$ & $\mathrm{R}^{2}$ \\
\cline { 2 - 5 } & $\mathrm{B}$ & $\begin{array}{c}\text { Standard } \\
\text { Error }\end{array}$ & & & & \\
\hline $\begin{array}{l}\text { Kinerja } \\
\text { Manajerial (Y) }\end{array}$ & 4.946 & 4.941 & 1.001 & 0.391 & 0.594 & 0.353 \\
$\begin{array}{l}\text { Penerapan } \\
\text { Akuntansi } \\
\text { Pertanggungjaw } \\
\text { aban (Xa) }\end{array}$ & 0.225 & 0.077 & 2.926 & 0.004 & & \\
Motivasi (Xb) & 0.373 & 0.133 & 2.800 & 0.006 & & \\
\hline
\end{tabular}

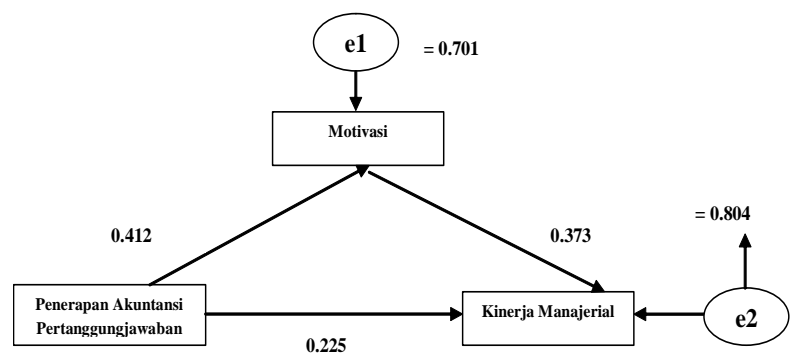

Gambar 1. Hasil Perhitungan Model Analisis Jalur (Path Analysis)

Anak panah e1 ke Motivasi menunjukkan jumlah variance variabel Motivasi yang yang tidak dijelaskan oleh Penerapan Akuntansi Pertanggungjawaban. Besar nilai e1 $=0,701$. Sedangkan anak panah dari e2 menuju Kinerja Manajerial menunjukkan bahwa Kinerja Manajerial yang tidak dapat dijelaskan oleh variabel Penerapan Akuntansi Pertanggungjawaban dengan Motivasi dan besarnya e2= 0,804 .

Untuk melihat pengaruh mediasi maka dilihat dari perkalian koefisien (p2xp3) signifikan atau tidak, diuji dengan Sobel Test (Imam Ghozali, 2011: 255). Berikut ini adalah cara perhitungannya.

a) Menghitung pengaruh langsung dan tidak langsung

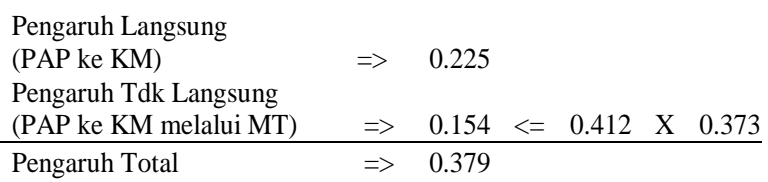

b) Menghitung dengan Sobel Test 


$$
\begin{aligned}
S p 2 p 3= & \sqrt{p 3^{2}} S p 2^{2}+p 2^{2} S p 3^{2}+S p 2^{2} S p 3^{2} \\
& =\sqrt{(0.373)^{2}}(0.039)^{2}+(0.412)^{2}(0.133)^{2}+(0.039)^{2}(0.133)^{2} \\
& =\sqrt{0.004}=0.057
\end{aligned}
$$

c) Menghitung nilai t statistik pengaruh mediasi

$t=\frac{p 2 p 3}{S p 2 p 3}$

$=\frac{(0.412)(0.373)}{0.057}=\frac{0.154}{0.057}=2.699$

Dari hasil perhitungan dapat diketahui bahwa pengaruh mediasi adalah signifikan. Hal ini ditunjukkan dengan perkalian koefisien sebesar 0,154. Hasil perkalian itu kemudian diuji dengan menggunakan Sobel Testdan menghasilkan t hitung 2,699 lebih besar dari t tabel dengan tingkat signifikansi 5\% yaitu sebesar 1,6594. Hal ini mendukung diterimanya hipotesis 3 yang menyatakan bahwa penerapan akuntansi pertanggungjawaban mempunyai pengaruh positif terhadap kinerja manajerial melalui motivasi.

\section{Pembahasan}

\section{a. Pengaruh Penerapan Akuntansi Pertanggungjawaban terhadap Kinerja Manajerial}

Pengujian terhadap hipotesis 1 yang menyatakan bahwa terdapat pengaruh antara penerapan akuntansi pertanggungjawaban terhadap kinerja manajerial terbukti. Hal ini bisa dilihat dari hasil output SPSS 17.0 dengan analisis regresi masing-masing variabel yang menunjukkan koefisien korelasi (R) yang positif $(0,552)$ dan nilai $\mathrm{t}$ hitung $>\mathrm{t}$ tabel sesuai pada taraf signifikansi 5\% (6,810> 1,6594).

Hasil tersebut menunjukkan adanya pengaruh yang positif dan signifikan antara penerapan akuntansi pertanggungjawaban terhadap kinerja manajerial.Semakin baik penerapan akuntansi pertanggungjawaban maka semakin baik kinerja manajer dalam menyelesaikan tugasnya.Dalam hal ini, penerapan akuntansi pertanggungjawaban memberikan peran dan tanggung jawab manajer yang jelas dalam anggaran, sehingga melalui ini akan dapat mempermudah dalam pengukuran kinerja manajer. 


\section{JURNAL NOMINAL / VOLUME II NOMOR II / TAHUN 2013}

\section{b. Pengaruh Penerapan Akuntansi Pertanggungjawaban terhadap Motivasi}

Pengujian terhadap hipotesis 2 yang menyatakan bahwa terdapat pengaruh antara penerapan akuntansi pertanggungjawaban terhadap motivasi terbukti. Hal ini bisa dilihat dari hasiloutput SPSS 17.0 dengan analisis regresi masing-masing variabel yang menunjukkan koefisienkorelasi $(R)$ yang positif $(0,713)$ dan nilai $t$ hitung > t tabelsesuai pada taraf signifikansi $5 \%(10,481>1,6594)$.

Hasil tersebut menunjukkan adanya pengaruh yang positif dan signifikan antara penerapan akuntansi pertanggungjawaban terhadap motivasi. Semakin baik penerapan akuntansi pertanggungjawaban di perusahaan akan meningkatkan motivasi manajer untuk bekerja semakin baik. Penerapan akuntansi pertanggungjawaban yang baik dapat mempermudah manajer dalam memantau pekerjaan yang dianggap kurang sesuai dengan tujuan perusahaan.Dalam hal ini pengontrolan anggaran dari masing-masing unit dapat terlihat secara jelas.Sebaliknya, dari sini dapat diketahui sejauh mana kinerja manajer dalam menjalankan tugasnya. Dengan demikian akan tampak kinerja manajer yang sesungguhnya dan perusahaan dapat menerapkan struktur penghargaan berdasarkan penilaian kinerja tersebut yang akan membawa dampak pada motivasi kerja karyawan.

\section{c. Pengaruh Penerapan Akuntansi Pertanggungjawaban terhadap Kinerja Manajerial Melalui Motivasi}

Pengujian terhadap hipotesis 3yang menyatakan bahwa terdapat pengaruh penerapan akuntansi pertanggungjawaban terhadap kinerja manajerial melalui motivasi terbukti. Hal ini bisa dilihat dari hasilperhitungan menunjukkan hasil penjumlahan koefisien yang positif $(0,379)$ dan dari hasil perhitungan $t$ yang menunjukkan nilai sebesar 2,699 lebih besar nilai dari t tabel (1,6594) sesuai dengan taraf signifikansi $5 \%$.

Hasil tersebut menunjukkan hipotesis 3 diterima, yang berarti bahwa penerapan akuntansi pertanggungjawaban berpengaruh terhadap kinerja manajerial melalui motivasi. Semakin baik penerapan akuntansi 


\section{JURNAL NOMINAL / VOLUME II NOMOR II / TAHUN 2013}

pertanggungjawaban di perusahaan akan dapat meningkatkan motivasi manajernya untuk bekerja dan pada akhirnya akan membuat kinerja manajerialnya semakin baik. Dalam hal ini penerapan akuntansi pertanggungjawaban yang baik dilakukan supaya masing-masing individu dapat secara jelas mengetahui tugas dan tanggungjawab pada daerah yang menjadi tanggungjawabnya, sehingga dapat memudahkan manajer dalam bekerja.Selain itu, peran penerapan akuntansi pertanggungjawaban sebagai dasar dalam penilaian kinerja setiap individu manajer dan menjadi dasar dalam struktur penghargaan perusahaan memberikan motivasi kepada manajer dalam bekerja.Motivasi tersebut muncul sebagai akibat adanya penilaian kinerja berdasarkan informasi akuntansi pertanggungjawaban. Melalui ini pula penilaian kinerja akan memacu peningkatan kinerja manajer, sehingga tujuan organisasi dapat tercapai sesuai dengan yang diharapkan.

\section{Keterbatasan}

a. Dalam pengumpulan data, penelitian ini menggunakan kuesioner. Oleh karena itu, data yang terkumpul hanya menggambarkan persepsi para responden pada saat menerjemahkan pernyataan-pernyataan yang ada sesuai persepsi para responden. Karena itu, kemungkinan terjadinya bias sangat memungkinkan, hal ini disebabkan perbedaan persepsi antara peneliti dan para responden terhadap pernyataan-pernyataan yang diajukan dan diterima.

b. Temuan hasil penelitian membuktikan bahwa selain penerapan akuntansi pertanggungjawaban dan motivasiterdapat faktor-faktor lain yang mempengaruhi baik tidaknya kinerja seseorang yang dibukti kan dengan akuntansi pertanggungjawaban dan motivasi hanya memberikan sumbangan sebesar 37,9\% terhadap kinerja manajerial, sedangkan $62,1 \%$ dijelaskan faktor lain yang tidak diteliti dalam penelitian ini.

c. Pada penelitian ini hanya menggunakan satu subjek penelitian, maka hasil penelitian masih kurang dapat digeneralisasi apalagi untuk perusahaan pada bidang yang lain. 


\section{JURNAL NOMINAL / VOLUME II NOMOR II / TAHUN 2013}

\section{PENUTUP}

\section{Simpulan}

a. Hasil penelitian ini menunjukkan adanya pengaruh yang positif dan signifikan antara penerapan akuntansi pertanggungjawaban terhadap kinerja manajerial yang ditunjukkan melalui nilai koefisien regresi yang bernilai positif $(0,379)$, nilai koefisien korelasi $(\mathrm{R})$ bernilai positif $(0,552)$, nilai $\mathrm{t}$ hitung $>\mathrm{t}$ tabel pada taraf signifikansi 5\% $(6,810>1,6594)$, koefisien determinasi $\left(R^{2}\right)$ sebesar 0,304. Hal ini berarti semakin baik penererapan akuntansi pertanggungjawaban maka semakin tinggi pula kinerja manajerialnya. Hipotesis pertama $(\mathrm{H} 1)$ yang menyatakan bahwa penerapan akuntansi pertanggungjawaban terhadap kinerja manajerial diterima.

b. Adanya pengaruh yang positif dan signifikan antara penerapan akuntansi pertanggungjawaban terhadap motivasiditunjukkan melalui nilai koefisien regresi yang bernilai positif $(0,412)$, nilai koefisien korelasi $(\mathrm{R})$ bernilai positif $(0,713)$, nilai $\mathrm{t}$ hitung $>\mathrm{t}$ tabel pada taraf signifikansi $5 \%(10,481>1,6594)$, serta koefisien determinasi $\left(\mathrm{R}^{2}\right)$ sebesar 0,509. Hal ini berarti semakin baik penererapan akuntansi pertanggungjawaban maka semakin tinggi pula motivasinya. Hipotesis kedua (H2) yang menyatakan bahwa penerapan akuntansi pertanggungjawaban terhadap motivasiditerima.

c. Hasil pengujian yang dilakukan juga menunjukkan adanya pengaruh yang positif dan signifikan antara penerapan akuntansi pertanggungjawaban terhadap kinerja manajerial melalui motivasi yang ditunjukkan dengan hasil penjumlahan koefisien yang positif $(0,379)$ perhitungan menggunakan Sobel Test yang menghasilkan t hitung $>\mathrm{t}$ tabel pada taraf signifikansi $5 \%(2,699>1,6594)$. Hal ini berarti semakin baik penerapan akuntansi pertanggungjawaban di perusahaan akan meningkatkan motivasi manajernya untuk bekerja dan pada akhirnya akan membuat kinerja manajerialnya juga semakin baik. Dengan demikian hipotesis 3 yang menyatakan penerapan akuntansi 


\section{JURNAL NOMINAL / VOLUME II NOMOR II / TAHUN 2013}

pertanggungjawaban mempunyai pengaruh positif terhadap kinerja manajerial melalui motivasi didukung olehpenelitian ini.

\section{Saran}

a. Bagi pihak PT Taman Wisata Candi Borobudur, Prambanan dan Ratu Boko

1) Perusahaan telah menerapkan sistem akuntansi pertanggungjawaban yang cukup memadai dengan memiliki struktur organisasi yang telah memuat garis wewenang dan tanggung jawab secara jelas untuk setiap tingkatan manajemen. Akan tetapi, sistem akuntansi pertanggungjawaban yang telah dipraktikkan perusahaan kurang dapat memisahkan biaya dan pendapatan yang dapat dikendalikan dan tidak dapat dikendalikan oleh manajer. Hal ini dapat menyebabkan penerapan akuntansi pertanggungjawaban kurang maksimal, yang akan berdampak pada motivasi dalam bekerja menjadi rendah. Oleh karena itu perusahaan diharapkan dapat mendesain dan menerapkan sistem akuntansi pertanggungjawaban yang baik, sehingga kinerja manajernya akan menjadi baik.

2) Perusahaan memberikan kesempatan bagi manajernya untuk mengaktualisasikan diri dengan memberikan saran dan kritik agar manajernya maju, sehingga manajer akan selalu berusaha sebaikbaiknya dalam menyelesaikan pekerjaannya walaupun harus lembur. Sebaliknya, manajer terkadang masih merasakan gaji yang mereka terima belum sesuai dengan kebutuhan mereka dan juga perusahaan belum adil dalam memberikan promosi jabatan kepada para manajernya. Dengan demikian perusahaan diharapkan dapat meninjau kembali prosedur promosi jabatan dan gaji yang diberikan apakah sudah bisa memenuhi kebutuhan para manajernya atau belum.

3) Manajer memiliki kemampuan yang tinggi dalam mengevaluasi kinerja bawahan mereka, akantetapi kemampuan mereka dalam perencanaan masih dirasa kurang. Untuk itu diharapkan perusahaan lebih mengembangkan kemampuan para manajernya dalam menyusun 


\section{JURNAL NOMINAL / VOLUME II NOMOR II / TAHUN 2013}

perencanaan seperti menentukan tujuan, kebijakan dan tindakan pelaksanaan untuk mencapai visi-misi perusahaan.

\section{b. Bagi peneliti selanjutnya:}

1) Hasil penelitian menunjukkan bahwa akuntansi pertanggungjawaban dan motivasi hanya memberikan sumbangan sebesar 37,9\%terhadap kinerja manajerial, sedangkan $62,1 \%$ dijelaskan faktor lain yang tidak diteliti dalam penelitian ini. Oleh sebab itu, peneliti selanjutnya dapat menambahkan variabel yang menjadi faktor lain dalam kinerja manajerial.

2) Penelitian selanjutnya diharapkan untuk menambah subjek penelitian, yaitu menggunakan beberapa perusahaan agar data penelitian lebih variatif dan kemampuan generalisasi lebih baik.

\section{E. DAFTAR PUSTAKA}

Anonim.(2013). "Tentang Perusahaan". Diambil dari: (www.bumn.go.id/borobudur/tentang-kami/tentang-perusahaan/), pada tanggal 16/02/2013, 21:00 WIB)

Atef Aqeel Al-Bawab. (2012). Impact of Decentralization and Responsibility Accounting in Performance Evaluation for The Decentralized Entities at the Yemenian Banks (An Empirical study). Interdisciplinary Journal of Contemporary Research In Business. Assistant professor Accounting Department Jerash University. Vol 3, No 11 halaman 611626.

Diana Putri. (2005). Hubungan Penerapan Akuntansi Pertanggungjawaban dengan Kinerja Manajer Pusat Investasi (Studi pada bengkel di Bandung).Skripsi.Mahasiswa Jurusan Akuntansi Universitas Widyatama.

Eddy Laberto. (2001). Pengaruh Partisipasi Penyusunan Anggaran Terhadap Kinerja Manajerial dengan Motivasi Sebagai Variabel Intervening.Tesis.Mahasiswa Pasca Sarjana Program Studi Magister Manajemen Universitas Diponegoro. 


\section{JURNAL NOMINAL / VOLUME II NOMOR II / TAHUN 2013}

Eka Dya Ayu Oktaviani. (2012). Hubungan Penerapan Akuntansi Pertanggungjawaban Dengan Kinerja Manajer Pada PT. Garam (Persero) Di Surabaya.Skripsi. Mahasiswa Jurusan Akuntansi Universitas Pembangunan Nasional "Veteran".

Imam Ghozali. (2011). Aplikasi Analisis Multivariate dengan Program SPSS, Edisi kelima. Semarang: Badan Penerbit Universitas Diponegoro.

Kunti Aprilia Risanti. (2012). Analisis Pengaruh Motivasi Kerja Terhadap Produktivitas Kerja Karyawan Pada Perusahaan Daerah Air Minum Kota Makassar.Skripsi. Mahasiswa Jurusan Manajemen Universitas Hasanuddin.

Mulyadi. (1997). Akuntansi Manajemen: Konsep, Manfaat dan Rekayasa, Edisi kedua. Yogyakarta:YKPN.

Robert L. Mathis dan John H. Jackson.(2006). Human Resource Management, Manajemen Sumber Daya Manusia. Edisi Sepuluh. (Alih Bahasa: Diana Angelica). Jakarta: Salemba Empat.

Tony Listianto dan Bambang Setiaji.(2007). Pengaruh Motivasi, Kepuasan, dan Disiplin Kerja Terhadap Kinerja Karyawan (Studi Kasus di Lingkungan Pegawai Kantor PDAM Kota Surakarta).Jurnal Manajemen. Program Pascasarjana Universitas Muhammadiyah Surakarta.

T. A. Mahoney, T. H. Jerdee, \& Carroll Jr. S. J. (1963). Development of Managerial Performance: A research approach. Cincinnati: SouthWestern. 